\title{
IMPLEMENTING RECIPROCAL TEACHING METHOD IN IMPROVE THE STUDENTS' READING COMPREHENSION ABILITY
}

\author{
Syaiful Islam \\ Universitas Nurul Jadid \\ syaifulislam182@gmail.com
}

\begin{abstract}
This research was designed to improve the students' reading comprehension in English through the implementation of Reciprocal Teaching Method. The research employed a collaborative classroom action research design in which the researcher and the collaborative teacher worked together in preparing a suitable procedure of Reciprocal Teaching Method, designing the lesson plan, determining of the criteria of success, implementing the action, observing, and doing reflections. The subjects of this research were 40 students of Grade XI BHS 2 at MA. Nurul Jadid Problolinggo in the academic year 2019/2020. The data of this research were obtained through (1) observation sheet, to obtain information about teacher's and the students' activities and performance during the implementation of Reciprocal Teaching Method, (2) quiz, to identify whether the students had made progress in reading comprehension, and (3) questionnaire, to get information from the students whether the strategy applied could motivate the students to actively involve during the teaching and learning process. The result of the research showed that the Reciprocal Teaching Method in the teaching-learning of reading comprehension was effective in improving the students' reading comprehension. The improvement was indicated by the increase of the students' average score throughout the cycle of action that was 72.63 in the preliminary study; 79.88 in the test of Cycle 1. Besides, students were motivated and active in the class using the method in terms of learning to work together and to help each other in a group with different competence, which was showed by the result of their works.
\end{abstract}

Keywords: reciprocal teaching method, improving, reading comprehension

\section{A. INTRODUCTION}

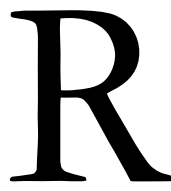

eading is one of English language skills considered important for the students' growth as an individual in many aspects of life. Every day, the students cannot escape from reading activity. We read newspaper, report, messages, books, notes, and many other writings. That is why students are taught reading skill at school. By reading, the students will know how English is used in printed and written forms. According to Rivers (1981:259) the most important activity in any language class is reading. Reading is not only a source of information and a pleasurable activity, but also a means of consolidating one's knowledge of a language. In other words, reading activities can bring many benefits for students such as to get information, pleasure and knowledge.

With the importance of reading, the students should be well prepared with the skill as early as possible in order that they are accustomed to comprehending what they read in their daily life. Leipzig (2001:1) states that in reading activity we are not only reading the text, but also trying to understand what we are reading. Reading requires words recognition, 
comprehension, and fluency. Djiwandono (1996:63) also states that to understand all types of information in an array of the text, it requires not only the reading activity, but also ability to understand the content. In addition, he states that without the ability to understand the content, one cannot absorb or comprehend a lot of information quickly, accurately, and easily. According the importance of reading, reading should become the main emphasis in English teaching program in Indonesia, particularly for the senior high school students. Yet it does not mean that the other skills of English like listening, speaking, and writing are not important.

There are several attempts which have been made to overcome the problems afore mentioned, such as revising the curriculum, training, conducting upgrading, workshops, selecting authentic and appropriate sources of materials, etc. However, those efforts will not be successful if the English teachers do not use appropriate methods and strategies of teaching in classroom.

In connection with methods and strategies of teaching, Bond, et al. (1979:110) stated that the teacher who tends to implement monotonous methods and techniques will reduce the students' interest and motivation. These monotonous methods and techniques produce unhappy learning-teaching atmosphere. The students are reluctant and do not like English anymore. They join the English lesson just to follow the schedule set by the school. This condition makes it difficult for the teacher to achieve the optimum instructional objective. Consequently, it leads to low students' achievement in reading.

Madrasah Aliyah Nurul Jadid Karanganyar Paiton Probolinggo, one of the senior high schools under the Ministry of Religion Affair, also has similar problems that are the students of the school have difficulties to achieve the optimum instructional objective of reading. The researcher, as one of the English teachers of the school, has experienced the difficulties himself during three years of my teaching there. In addition, the information and experience of my English colleagues show that the students' achievement of English has not fulfilled the requirement of minimum passing standard set by the school was 75 . When the researcher conducted the teaching and learning process in the eleventh-grade students, they showed that their ability in comprehending a reading text was still under the minimum passing score. The students found it difficult to answer the questions based on the text given. The average score in the formative tests was only 68.85 on the average. Furthermore, the average score of English test in the preliminary study conducted on Thursday, January 2, 2020 was 72.63. These results did not meet the minimum passing grade criteria of English in MA.Nurul Jadid.

The condition above might be caused by several factors: first, the students' reading skills in finding information in the text were still insufficient; second, they have limited vocabulary; 
and third, their motivation to learn English was also still low. Many of them are off-task during the learning-teaching process.

The problems above are realized by the researcher as one of the English teachers of the school. They are possibly caused by several factors which might come from the English teachers themselves. We still tended to apply monotonous method and technique and did not implement appropriate strategies which supported our learning-teaching process of reading comprehension. Classical teaching was still as the basis of our teaching of reading skill. We gave and read for our students a reading material then asked them to read it. Then, they looked for difficult words or those which they still do not understand individually. At the end, we instructed the students to answer the questions related to the text.

Those problems might be overcome if the teachers know the students' conditions, and then they can decide the right method or strategy to be applied for their students (Huda, 1999:27). He also supports that one of the many factors influencing the failure of the students' reading comprehension has been the fact that they do not learn optimally with the theoretical principles underlying language teaching strategies. Here, the teacher should know some strategies of teaching reading as the basis of the teaching and learning process.

Concerning these problems, the researcher considered that it was necessary to do some efforts which enable the students to read English well. One of the efforts was applying appropriate strategies that created vivid classroom atmosphere. Through the strategy, the researcher expected to enhance the students' motivation and developed their proficiencies and skills in expressing their thoughts or ideas independently.

One of the methods he wanted to implement was Reciprocal Teaching Method. It was chosen since he was inspired by an idea of improving the students' reading comprehension through Reciprocal Teaching Method stated by Roe, et al. (1995:114). Related to this, there were two researchers of post graduate students at State University of Malang who had implemented the Reciprocal Teaching Method. Indrayani (2005:48) had investigated the implementation of Reciprocal Teaching Method for the teaching of ESP at the Biology Department of the State University of Malang (a case study), and Zakiya (2008:65) had investigated the improvement of reading comprehension on the fourth semester English students of Islamic University of Malang using Reciprocal Teaching Method. Both researchers said that the implementation of Reciprocal Teaching Method showed both the teacher and the students executed their duties actively and cooperatively in the teaching and learning process through the strategies applied in Reciprocal Teaching Method. The teacher gave assistance as needed and the students worked together and helped each other to understand 
the text provided. The students had positive reaction towards the implementation of Reciprocal Teaching Method.

\section{B. REVIEW OF LITERATURE}

Teaching is not an easy matter. The teacher always tries to find a better way to teach reading effectively and efficiently. Many methods and strategies have been tried out with the hope that this will be the right way to teach reading. Since mostly the success of teaching of reading depends on the condition of the class, the teacher will be the one who knows more about the right strategy in teaching his or her students. One of the ways is called Reciprocal Teaching Method.

In the study of Reciprocal Teaching Method, the discussion will include four matters: the history of Reciprocal Teaching Method, the definition of Reciprocal Teaching Method, the purpose of Reciprocal Teaching Method, and the reading strategies of Reciprocal Teaching Method which include predicting strategy, clarifying strategy, questioning strategy, and summarizing strategy.

Reciprocal Teaching Method is a method of reading comprehension instruction developed by Ann L. Brown from University Illinois and Annemarie S. Palincsar from University of Michigan in 1984 (Lubliner, 2001:1-5). Reciprocal Teaching Method is designed to provide a simple introduction to group discussion strategies aimed at understanding and remembering text content.

Reciprocal Teaching Method is based on Lev Vigotsky's ZPD, a Russian psychologist, contributed significantly to social constructivist epistemology. According to Oxford (1997:19), Vygotsky introduced the concept of the zone of proximal development (ZPD), that is, the realm of potential learning that each learner could reach within a given developmental span under optimal circumstances and with the best possible support from the teacher and other from the environment. Zone of Proximal Development is negotiated between the teacher and the students (or between the students and peers or others). Vygotsky describes the of proximal development as the distance between the actual development level as determined by independent problem-solving and the level of potential development as determined through problem-solving under adult guidance or in collaboration with more capable peers.

Vygotsky recognized that ideas have social origins; they are constructed through communication with others. An individual's cognitive system is a result of communication in social group and cannot be separated from social life (Oxford, 1997:27). He also adds that for Vygotsky, the teacher acts as a facilitator or guide and the provider of assistance. Teachers 
perform a great service to students by providing any and all forms of assistance that might help students develop their language and cultural skills. In the second language classroom, Vygotsky's idea of assistance might include a hint or clue, a word of praise, a suggestion, a learning strategy, a grammar reminder, or an intensive review - anything that the particular L2 student needs at a given time. When the learner needs the greatest assistance, the teacher gives "scaffolding" to ensure that the learner's constructs will continue to grow stronger and more complex. As the learner requires less help, the teacher slowly removes the no longer needs scaffolding that prop up the learner, and the learner becomes increasingly self-directed and self-empowered. This turn-taking is called reciprocal teaching.

Experts give definition of Reciprocal Teaching Method. Palincsar and Brown (1984:153) describe the concept of Reciprocal Teaching Method as an instructional procedure originally designed to enhance students' reading comprehension. The term "reciprocal" describes the nature of the instructions each person has in response to the other(s). This dialogue is structured by the use of four strategies: predicting, clarifying, questioning, and summarizing. The teacher and students take turns assuming the role of dialogue leader.

Reciprocal Teaching Method takes place as a dialogue between teachers and students (or student leader and members of the group) that results in students learning how to construct meaning regarding segments of the text (Palincsar in Villetto et al., 2002:1-3). In this activity, the teacher and the students take turns assuming the role of teacher in leading the dialogue. This method can be used in all subject areas for content reading and was originally designed to teach poor readers to use reading activities employed by good readers to enhance reading comprehension (Seventh-day Adventist North American Division office of education, 2000:1).

Reciprocal Teaching Method thus parallels the definition of reading that describes the process as a dynamic interaction between the reader and the text in the reader's attempt to construct the meaning from the text. Using prior knowledge and experience as a channel, readers learn new information, main ideas, make connections, and generally make sense from the text as intended by the author. Readers construct meaning by relying on prior experience to parallel, contrast or affirm what the author suggests (Carter, 2001:96).

As for the final definition, Palincsar, Ransom and Derber in Hartman (1997:1) state that there are four principles adhering to Reciprocal Teaching Method, as the following: (1) The purpose of reciprocal teaching to improve reading comprehension by equipping students with strategies needed to monitor comprehension and construct meaning, (2) The teacher (or tutor and students share responsibility for acquiring the reading strategies. After initially assuming 
major responsibility these strategies, the teacher gradually shifts responsibility to the students, (3) every student is expected to participate in discussion. The teacher helps as needed to support student's participation, (4) the teacher regularly tries to turn control of the dialogues over the students. Those gaps will researcher will find out.

\section{METHOD}

This research was categorized as collaborative classroom action research since the researcher and one of the English teachers at $M A$. Nurul Jadid worked together in conducting the research. This design is employed to solve the students' reading comprehension. Considering the students' poor reading comprehension skill, the researcher intended to apply a more effective way to improve the students' reading comprehension skill in two aspects of reading comprehension, namely: literal comprehension and inferential comprehension. The researcher used random sampling technique and XI BHS 2 was chosen. The students involved in this research were the students of XI BHS 2. It consisted of forty students.

Before conducting the research, the researcher conducted a preliminary study that aimed at identifying the real and current condition of the class, to see the students' problem in reading comprehension. The writer observed the teaching and learning process of reading comprehension as well as the materials and media. These activities were done in order to design an appropriate planning to solve the problem.

The preliminary study was conducted by the researcher; it was found that many of the students at the school had low ability in comprehending texts given to them in which it was indicated by the average score of English test in preliminary study conducted on Thursday, January 2, 2020. The average score of English test in preliminary study was 72.63 in which it did not reach the minimum standard score for English set by the Madrasah 75. Also, Reciprocal Teaching Method in the teaching of reading comprehension had not been applied yet and seemed suitable to be implemented.

The teaching procedures used in the implementation of the plan were developed based on the Reciprocal Teaching Method including three phases of reading activities. They were pre-reading, whilst-reading, and post-reading.

Pre-reading consists of the activities, namely: setting the students into groups of four, showing the students some pictures related to the topic, asking the students some guiding questions about the pictures/the topic, and asking the students to express their ideas about the topic freely.

Meanwhile, in whilst-reading, the activities was classified into four strategies, they were: 1) predicting, the activities were asking and guiding the students to predict what they thought 
they would read based on the pictures given, asking the students to jot down 2-3 predictions, having the students discuss their predictions in groups, asking and guiding the students to predict what the rest of the passage is about; 2) clarifying, the activities were assigning the students to identify/list any unfamiliar words from the text, asking and guiding the students to find the meaning of the unfamiliar words listed/identified before, having the students discuss what confused them in groups; 3) questioning, the activities were having the students to identify the kinds of information that provides the substance for an appropriate question, asking the students to frame questions before, during, and after reading, having the students to read one question to the group, and having the students to continue discussing the rest of their questions; and 4) summarizing, the activities were having the students read the text once again rapidly, asking the students to jot down those main ideas on paper, having the students discussed what to summarize in groups, and having the students summarize the text content.

The last phase of reading activities is post-reading. The activity in this phase was distributing reading comprehension quiz including literal and inferential comprehension questions and instructing students to complete.

In order to be easier to monitor the implementation of the learning-teaching process in the classroom, some instruments were prepared. The instruments used in this study were observation forms, and tests.

The observation forms were designed to collect data about the teacher and the students' activities during teaching and learning process. For the teacher, the observation form as used to observe the teacher's performance in teaching reading comprehension by using Reciprocal Teaching Method. Meanwhile, for the students, the observation forms were focused on their performance when the method was being applied.

When designing a test instrument, the researcher had to consider how to score and to grade the result of the test. As Brown (2004: 61) stated that your scoring plan reflects the relative weight that you place on each item in each section. Moreover, Sulistyo (2007: 104105) classifies scoring into two based on the test taker's response is viewed and treated. The first type is dichotomous scoring. The number utilized in this kind of scoring is 0 (zero) and 10 (ten). The test that commonly requires this dichotomous scoring is multiple-choice, truefalse, correct- incorrect and any other formats that suggest a dichotomy in producing responses. The second type is continuous scoring. The test taker's response is considered as having a graduation or degree in it. In this way, a test taker's response may be scored as $0,1,2$, 3,4 , or 5 . Depending on the nature of the response according to the scoring scheme utilized. Since the multiple-choice was used in designing the test instrument, this research used 
dichotomous scoring which the number utilized is 0 and 10.10 (ten) was assigned to a correct answer and 0 (zero) to an incorrect answer.

The criteria of success were set to indicate the improvement of the students' reading comprehension skill by applying Reciprocal Teaching Method. The students' improvement in reading comprehension after the implementation of the action research was described in two kinds of comprehension, namely; literal comprehension and inferential comprehension. In this case, the success is determined by the following criterion. The action is successful if majority of the students $(\geq 85 \%$ students of the whole class) achieves reading score greater than or equal to 75 of the range that lies from $0-100$. The consideration of the score 75 as what has been set by school as the minimum learning mastery standard (KKM).

The data obtained in the study were in the form of filled in observation sheet, and students' scores. The former was concerning the process of the implementation of the action in the content of the learning-teaching process. They were derived from the result of observation. The later was obtained after joining the test conducted at the end of each cycle. In brief the sources of the data were the activities of the teacher and the students.

In order to make the data analysis easier, the data collected in each cycle was classified first based on the form of the data and were presented in an organized description. It means that the data concerning the result of observation and field-notes were elaborated qualitatively by using percentage. The qualitative analysis of the students' performance refers to the analysis, which showed the way the students' answer each question of the test. Meanwhile, quantitative analysis refers to computation of the students' scores to identify their mastery and the mean score obtained in each cycle. The results of the score computation was matched with the criteria of success. It was to ensure whether the criteria of success had been met.

\section{FINDINGS AND DISCUSSION}

\section{Findings}

There was cycle with four meetings for each cycle in conducting the Classroom Action Research (CAR). The three meetings were allocated to teach reading comprehension by implementing the Reciprocal Teaching Method and one meeting was allocated for assessment. The findings of the cycle are presented as follows.

The result of the observation on the teacher's performance at the first meeting showed that the teacher could follow the steps during the first action. However, there were sometimes some problems found during the implementation of the action. The first problem was the teacher could not organize the allocated time that it made the other process of teaching lack of time. The immediate help given by the teacher to the students without asking the 
teammates made the students not responsible for solving their problems. The next problem was the lack of attention from the teacher to the low achievers. It caused them unmotivated to participate in all activities during the class discussion.

At the next meeting, there had been an improvement towards some weaknesses of the teacher's performance found in the first meeting. The result of the observation showed that the teacher could manage the time allocated of the teaching process. The teacher could also encourage the students to share their problem with their teammates rather than immediately being involved in helping them. In addition, he gave attention to the low achievers by giving them an opportunity to answer the questions given. It was also found that the teacher could follow the steps required in the lesson plan.

The previous analysis to the teacher's performance brought a good influence on the third action. It was found that the teacher explained the task to the students clearly, involved all students of each group to participate actively in the group discussion, and gave more opportunity to groups to solve their problems. The results of the observation also showed that the teacher could follow the steps required in the lesson plan well. However, there were still some weaknesses found in implementing the method, such as organizing the group members, and encouraging the students to help their teammates.

The problems also came from the students which appeared during the teaching and learning process at the first meeting. Some of them could not give responses to the oral questions dealing with the pictures shown in the pre-reading activity. It indicated that the students' word recognition was still insufficient. It was also identified that the students looked up in the dictionary the unfamiliar words in order to understand every single word in the reading text during the whilst-reading stage. It was found that during the discussion that some of the students still worked individually although they were involved in a group activity. It was also found that although they faced problems with their tasks, they were reluctant to ask their teammates or the teacher for some help. Those facts indicated that the students were not yet accustomed to do any tasks before in group.

Based on the weaknesses found in the first meeting, some efforts were done to make all the students involved in the tasks in the second meeting. To reduce the domination of the high achievers in the pre-reading stage, the teacher gave attention to the low achievers by giving them the opportunities to answer the questions given. In the whilst-reading stage, the students were not asked to look up all the unfamiliar words that were essential for understanding the text. The collaborative situation seemingly started when they played their roles in accomplishing the reading comprehension task. 
At the third meeting, the students were encouraged to see the benefits of working together, to learn to relate, to learn to help and to enact their roles. As a result, all the groups were active to accomplish the task together, some of them started to ask for and to give help in their groups.

The analysis of the students' learning result was done based on the students' work during the teaching and learning process and the results of their reading comprehension test at the end of the cycle. In terms of the students' work result, the improvement was examined from the ability to predict, clarify, generate the questions, and summarize the text. At the first meeting, it was found that from the whole groups, only 1 predictor could predict the text, 2 clarifiers could clarify the text, 4 questioners could generate the questions, and 1 summarizer could summarize the text. At the second meeting, it was found that there were 6 predictors that could predict the text, 6 clarifiers that could clarify the text, and 7 questioners and the summarizers could do their job well. Moreover, in the third meeting, it was found that there were 7 predictors that could predict the text, 6 clarifiers that could clarify the text, and 7 questioners and the summarizers could do their job well

Based on the description above, it could be said that the students' ability to predict the text, clarify the text, generate the questions, and summarize the text were improved. In other words, during the three meetings of the study, the students made improvement on their ability to comprehend a text. Furthermore, based on the result of the students' reading comprehension test at the end of the study, it was also found that an improvement had been made in line with the students' achievement in reading comprehension as shown by the scores obtained on the test.

Besides, the students' answers in the post reading stage were analysed, it was found out that from the 5 questions given, including literal and inferential questions, most of the students could answer 1 to 2 questions correctly. In the second meeting, it was found out that from the 5 questions given most of them could answer 2 to 3 questions well, whereas in the third meeting it was found out that the students could answer 3 to 4 questions well.

The questionnaire was done. The main purpose of implementing questionnaire, to get information from the students whether the strategy applied could motivate the students to actively involve during the teaching and learning process. The questionnaire of the students consisted of three points, were general opinion about English, teaching and learning process, and self-assessment.

Evaluation was done on the result of teaching learning of reading comprehension using Reciprocal teaching method. The evaluation was focus on the result of the test at the 
end of Cycle 1. Generally, the teaching-learning process in cycle 1 was significantly good. The students' averages score met the criteria of success.

The test to measure the success of the teaching was conducted on Wednesday, January 23, 2020. The researcher and the collaborator administered a test for cycle 1 to the students. The material of the test was based on the topic for the eleventh graders of BAHASA 2 at MA. Nurul Jadid. The test consisted of 20 items in the form of multiple choices. The objective of the test was to see whether $85 \%$ of the students got scores greater than or equal to 75 as required in this research. The time allocated in for the test was 90 minutes.

The result of the test showed that the highest score is 95 and the lowest score is 70 . As many as 38 students (95\%) get the score of 75 or higher and only 2 students (5\%) get lower than 75 .

Reflection was performed to make sure whether the action given was successful. The criterion of success was $85 \%$ of the students got scores greater than or equal to 75 . The result shows that 38 students or $95 \%$ of the students get score higher or the same as 75 . According to the result of the reading comprehension test in this cycle 1, it was found that the students' reading comprehension was improved. In other words, it can be concluded that the implementation of Reciprocal Teaching Method was effective in improving the students' reading comprehension.

\section{Discussion}

The findings of the research showed that Reciprocal Teaching Method could improve the students' reading comprehension. This can be studied from the results of the pre-test and the tests conducted during the first cycle. The test in preliminary study conducted prior to the implementation of the action showed that the students' reading comprehension was low. Some of the students obtained score 60 with the mean score 72.63 . From 40 students who joined the test, only 12 students obtained scores higher than or equal to 75 , while the rest or 28 students obtained less than 75. However, when the Reciprocal Teaching Method was applied the students' reading comprehension gradually improved. The result of the test in cycle 1 showed that from 10 literal questions, most of the students could answer 8 questions correctly and only some students could answer correctly the rest 2 questions. It was also found out that from of 10 inferential questions, most of the students could answer 7 questions correctly and only some of the students could answer correctly the rest 3 questions. It indicated that the students still encountered difficulties in answering inferential questions rather than literal questions. However, the students' learning result showed that there was a 
better improvement on reading comprehension compared with the result of the preliminary. The students' maximum score reached 95 with the mean score 79.88. This result was in line with Komariah, et al (2015). The results showed that the students were more active and productive in the reading classroom after RTM sessions and their reading proficiency improved (Komariah, Ramadhona, \& Silviyanti, 2015). And, a research by Davidson support the result of this research. He found that Research showed students practice Reciprocal Teaching strategies increase their reading

comprehension level (Davidson, 2015).

In conclusion, the Reciprocal Teaching Method promotes higher academic achievement than individualistic or competitive learning experiences do. The success of implementing Reciprocal Teaching Method in teaching reading comprehension was influenced by some factors. The first factor was setting the students into heterogeneous groups according to achievement levels. It made them learn from each other. The low and the middle achievers had opportunity to ask help from the high achievers.

The second was an active role by the researcher and his collaborator in monitoring and facilitating the students. During the group work, they monitored the students whether the students how to do the task and how to work together. In addition, as the facilitator, the researcher and his collaborator encouraged the students to participate actively and helped them whenever needed.

The third factor was the group reward. By applying it, the students could encourage one another to learn more successfully in groups. They also might feel that they were studying not just for themselves, but also for the whole group.

The next factor was the meaningful roles of each member in groups. The roles of a predictor, a clarifier, a questioner, and a summarizer could encourage each learner to play an active role in the group. The role of predictors, for examples, focused on predicting what they think they will read based on the picture given and what the rest of the passage will be about.

Based on the data presented in the previous section, it was found that Reciprocal Teaching Method which carried out on three systematic phases: pre-reading, whilst-reading, and post-reading could bring a good progress on the students' reading comprehension (Harmer, 2001). The implication of the method towards reading comprehension was evidenced by the students' willingness to share ideas among the teammates and to help each other in understanding the reading materials and the tasks. When the students were given the tasks to be completed in groups, they were active to share ideas in order to reach agreement on their groups' answers. During the discussion, the students took turns to offer their 
opinion. In this sense, they could apply cooperative skills such as active listening, allowing one person to speak, and taking turns.

Since the students were assigned in heterogeneous groups in which each group had high, middle, and low achiever students, the researcher stressed them to help each member in learning the assigned materials. The students had to learn to help and ask for help. It helped the students improve their reading comprehension in literal and inferential levels. Besides, helping behaviours could build a positive peer relationship.

Furthermore, the anxiety and shyness could be reduced because the students worked in small groups. Why they were asked to report their works to the whole class, they might feel confidence because their answer was not just from their whole group.

However, the method brought positive impact on the students in some aspects. First, the students were more motivated to study because Reciprocal Teaching Method promoted work group in which the students could learn from one another by sharing ideas among the teammates. Second, the students could increase their comprehension of the material because they were giving help to and receiving help from their group mates and not just the teacher. Third, the students could spend time on task when working together in group. Fourth, the students could grow socially when they worked together.

\section{E. CONCLUSION}

On the basis of the research findings, there are some conclusions as the answers to the research problem of the study.

First, the implementation of Reciprocal Teaching Method could improve the students' reading comprehension achievement in three levels of reading comprehension: literal, inferential, and evaluative levels. The improvement of the students' reading comprehension achievement in the three levels of comprehension is shown by the percentage of the students' higher score based on the standard score stated in the criterion of success: 75.00 , namely: 30 $\%$ in the test for preliminary study, $70 \%$ in the test for cycle 1 , in which before conducting the tests of each cycle, a reading comprehension task was given to the students for each meeting.

The second, the students' ability can be improved by implementing Reciprocal Teaching Method which consists of three phases of teaching reading comprehension, they are prereading, whilst-reading, and post-reading activity. The pre-reading activity was done to help the students activate and use their relevant prior knowledge. The researcher varied the activity by asking some questions about the pictures. In the whilst-reading activity, the students were asked to predict the text, generate the questions of the text, and summarized the text. Their 
activities were always monitored by the researcher and his collaborator to make sure that the students understood how to do the task and how to work together. Then, the researcher checked the groups' works. In the post-reading activity, the students were asked to complete the reading comprehension task including literal and inferential questions. The findings indicated that in the first meeting the students completed this task. However, some students still made mistakes in answering the prepared questions, especially in the inferential questions. Meanwhile, in the second and third meeting the students could improve to answer the prepared questions better than in the previous meetings. The improvement could be estimated from the number of the students who were actively involved in the task assigned during the meeting. Besides, all of them could improve to answer the prepared questions easily.

Finally, the students had a positive response towards the implementation of Reciprocal Teaching Method. The method was able to make them motivated to study because they could learn one another by sharing ideas among the teammates. Also, the students could improve their understanding of the text because they give help and receive help from their group mates and the researcher. Furthermore, they could spend less time on task when working together in a group.

\section{REFERENCES}

Best. J.W.. 1981. Research in Education. Englewood Cliffs: Prentice Hall, Inc.

Bond, G.L., Tinker, M.A. \& Wasson, B.W. 1979. Reading Difficulties: Their Diagnosis and Correction (4 $4^{\text {th }} \mathrm{Ed}$.). London: Prentice Hall, Inc.

Brown, H.D. 2001. Teaching by Principles: An interactive approach to Language Pedagogy (2nd Ed.). San Francisco: Addison Wesley.

Burns, A., Solomon, N. \& Hood, S. 1996. Focus on Reading (New Edition). Sydney: National Centre for English Language Teaching and Research.

Davidson, J. (2015). Improving Reading Comprehension through Reciprocal Teaching (Doctoral dissertation, Northwest Missouri State University).

Djiwandono, Soenardi M. 1996. Tes Bahasa dalam Pengajaran. FPBS-IKIP Malang : ITB Bandung.

Harmer, Jeremy. 2001. The Practice of English Language Teaching (3rd ed.). London: Pearson Education Limited.

Huda, N. 1999. Language Learning and Teaching. Malang: Universitas Negeri Malang Publisher. 
Indrayani. N. 2005. The Implementation of Reciprocal Teaching Method for the Teaching of ESP at the Biology Department of the State University of Malang (A Case Study). Malang: Unpublished Thesis.

Komariah, E., Ramadhona, P. A. R., \& Silviyanti, T. M. (2015). Improving reading comprehension through reciprocal teaching method. Studies in English Language and Education, 2(2), 87-102.

Leipzig, Diane Henry. 2001. What is Reading? WETA. (Online). URL: http://http://www.readingrockets.org/article/352. (Accessed: 2007, June 14th). McNiff, J. 1992. Action Research Principle and Practice. New York: Chapman and Hall Inc. Roe, Betty D., Barbara D. Stoodt and Paul C. Burns. 1995. Secondary School Reading Instruction: The Content Areas. Boston: Houghton Mifflin Company.

Sulistyo, G. H. 2011. Reading For Meaning. Malang: Pustaka Kaiswaran Press.

Zakiya, L.F.. 2008. Improving Reading Comprehension on the Fourth Semester English Students of Islamic University of Malang Using Reciprocal Teaching. Malang: Unpublished Thesis. 